\title{
Homo eroticus: Considerações acerca do conceito de Sodomia nos processos da Inquisição Portuguesa*
}

\section{Homo eroticus: Considerations about the concept of sodomy in the processes of the Portuguese Inquisition}

\author{
Edson Santos Silva Correio** \\ Wallas Jefferson Lima Correio***
}

Resumo: A associação entre a palavra "sodomia", de origem bíblica, e a palavra "homossexual", criada no século XIX pelo discurso médico, é recorrente no imaginário social. Mas essa identificação, longe de ser ingênua, estabelece uma relação complexa, pois deixa vir a lume indagações acerca das condições ideológicas, linguísticas e temáticas que possibilitam a reprodução de discursos referentes à condenação das práticas homoeróticas. Ancorado metodologicamente em autores como Michel Foucault, John Boswell e Jurandir Freire Costa, este artigo objetiva analisar o processo histórico-linguístico da associação dessas palavras e como isso se constitui em uma dificuldade para a escrita histórica.

Palavras-chave: Sexualidade; imaginário social; discurso

* Este texto é parte integrante da dissertação intitulada "O Entremeio de uma vida: o pecado de sodomia à luz do processo inquisitorial de Luís Gomes Godinho (1646-1650)", defendida em 2014 no Programa de Pós-Graduação em História da Universidade Estadual do CentroOeste - UNICENTRO-PR

** Possui graduação em Letras: Português/Inglês pela Faculdade de Filosofia, Ciências e Letras Santana (1991), mestrado em Literatura Portuguesa pela Faculdade de Filosofia, Letras e Ciências Humanas da Universidade de São Paulo (2001) e doutorado em Literatura Portuguesa, pela Universidade de São Paulo (2009).

Professor do Ensino Superior da Carreira do Magistério Público do Ensino Superior do Paraná, do Departamento de Letras, campus de Irati, da Universidade do Centro-Oeste do Paraná. Vice-Chefe do Departamento de Letras,campus Irati, Unicentro, vinculado ao Setor de Ciências Humanas, Letras e Artes, SEHLA/I. E-mail: jeremoabo@ig.com.br

***Mestre em História pela Universidade Estadual do Centro-Oeste, Paraná - UNICENTRO (2014). Graduado em História pela Universidade Potiguar - UnP (2011) e Especialista em História do Brasil pela mesma Universidade (2012). Área de atuação em História do Bra- 
sil Colonial, com foco principal nos seguintes temas: Identidades Sociais, Religiosidades, Corpo, Gênero, Relações de Poder, Discurso e Inquisição Portuguesa. Atualmente é professor da Secretaria de Estado da Educação - SEED-PR. E-mail: wallasjefferson@hotmail.com

\begin{abstract}
The association between the word "sodomy", of Biblical origin, and the word "homosexual", created by nineteenth-century medical discourse, is recurrent in the social imaginary. But this identification, far from being naive, establishes a complex relationship, because it brings within some questions about the ideological conditions, language and themes that it enables the repetition of discourses of condemnation of homoerotic practices. Methodologically anchored with authors such as Michel Foucault, John Boswell and Jurandir Freire Costa, this article aims to analyze the historical process of linguistic association of these words and how that constitutes a difficulty for historical writing.
\end{abstract}

Palavras-chave: Sexuality, social umaginary; speech

A questão que se coloca neste artigo está entre as mais antigas da história da inquisição portuguesa: o "pecado" de sodomia era entendido e assimilado pelos inquisidores com o que se denomina atualmente de "relações homossexuais"? Ela foi colocada, entre outros, por Ronaldo Vainfas em sua obra Trópico dos Pecados, fruto de sua tese defendida na USP em 1988. ${ }^{1}$ Essa mesma questão reapresentou-se em nossa mente ao analisar processos inquisitoriais relativos a casos de sodomia. Diante desse contexto, pareceu inevitável voltar a indagar as fontes com novas questões em relação àquelas dominantes nas muitas pesquisas de história. Colocada diante dos historiadores, trata-se de compreender melhor como o entrecruzamento das palavras "sodomia" e "homossexualidade" foi sendo construído e que consequência isso apresenta para os escritos históricos. Mas, há mais: a discussão acerca da associação entre sodomia e homossexualidade constitui também um exercício crítico destinado a compreender e a encaminhar questões que abrangem o imaginário social, o discurso religioso e as subjetividades coletivas dos homens do passado.

A necessidade de tal problematização advém do fato de que há divergências de opiniões entre os historiadores especializados no Brasil Colonial quanto ao que a sodomia significava entre os séculos XVI ao fins do XVIII e aos tipos de representações que a prática assumia no corpo social. Historiadores ligados às temáticas de Gênero, Inquisição, Sexualidade e Intolerância, que se debruçam em pesquisas referentes à sodomia, ao explicarem tópicos problemáticos referentes à questão, quase nunca discutem acerca do que ela realmente era. De onde essa palavra se origina? Que tipo de relação se operou ao longo do tempo entre a sodomia e a homossexualidade? E, mais 
importante ainda, como e quando a palavra sodomia passou a ser sinônimo de homossexualidade? Essas são algumas das questões que nos propomos a responder.

\section{Sodomia e homossexualidade: questões terminológicas}

Sodomia é um termo polissêmico e, como tal, pauta de intensos debates entre os historiadores. Constitui, como tantos outros, um vocábulo que marca as tensões que permeiam a luta simbólica pelo uso legítimo do conceito na área de História. Para além dessas tensões, a palavra está enredada em um coletivo de representações sociais. Uma saída para a compreensão desse conceito pode advir de uma análise semântica, nicho em que se abrigam os conceitos.

O termo carrega em si uma série de generalizações. Com efeito, "sodomizar" ou ser "sodomizado" por alguém foi, por muito tempo, uma ideia inextricavelmente ligada a noções culturais que traziam em seu âmago as noções de "pecado", "transgressão", "erro", "infração". Esses termos foram utilizados para indicar uma condição ou estado do sujeito que praticava o ato sodomítico: pecador, transgressor, infrator, etc. Trata-se, enfim, de uma palavra que esgotou toda sua razão de ser, especialmente a partir da Baixa Idade Média, em inclinações eróticas e sexuais por indivíduos do mesmo sexo biológico como bem o mostrou o historiador John Boswell. ${ }^{2}$ Mas, a ideia de que a sodomia possa equivaler ao que atualmente se denomina relações homossexuais e/ou homoafetivas já demanda, entretanto, algumas observações.

A primeira refere-se ao fato de a palavra remeter o pesquisador à cidade bíblica de Sodoma, narrada no Antigo Testamento. ${ }^{3}$ Ló, sobrinho de Abraão, foi o herói central de uma história que está descrita em pormenores no livro do Gênesis. A interpretação mais difundida pelas entidades religiosas relata que Ló teria hospedado dois anjos em sua residência. Uma turba vil de moradores de Sodoma (os sodomitas), inclusive rapazes e homens idosos, teria tentado invadir a casa de Ló, no intuito de estuprar os hóspedes angélicos. ${ }^{4} \mathrm{O}$ anfitrião buscou protegê-los, até mesmo oferecendo suas duas filhas virgens ao grupo de homens. Porém, a turba irada teria se arremessado fortemente contra Ló, em vista do que os visitantes angélicos puxaram-no para dentro e feriram os sodomitas com cegueira. No dia seguinte, depois de Ló, sua esposa e suas duas filhas terem deixado a cidade, Sodoma teria sido destruída com enxofre e fogo descidos dos céus ${ }^{5}$.

Essa explicação, bastante elementar, retomada indefinidamente, impôs-se a todos os cristãos. Esse breve relato foi o que tornou possível ao cristianismo apoiar a condenação e a renovação da hostilidade contra os homossexuais ao longo da história. Articulou normas, condutas e dispositivos ideológicos e institucionais, sendo um eficaz instrumento de justificação da 
perseguição aos relacionamentos entre iguais no Ocidente cristão. ${ }^{6}$ Baseandose em interpretações bíblicas seletivas e de cunho universal, a Igreja passaria a fabricar um coletivo de representações que fizeram da cidade de Sodoma um lugar perfilhado por indivíduos homossexuais. ${ }^{7}$ Sodomia passou a ser, desta forma, o nome pelo qual os teólogos, especialmente medievais, denominavam o que acreditavam ser a atividade sexual característica desses habitantes: o sexo entre homens. ${ }^{8}$

Análises exegéticas e revisionistas acerca de Sodoma sustentam, porém, que a atitude reprovável levada a cabo pelo grupo de sodomitas não consistira nas práticas sexuais em si, mas, sobretudo, na violação do código de hospitalidade vigente à época. Considerada lei sagrada entre os antigos hebreus, cercar viajantes de cuidados representava uma prática corrente. Estranho ou próximo ao grupo, o visitante deveria ser acolhido com um beijo. Além disso, um membro da casa, usualmente um servo, deveria lavar seus pés e o anfitrião deveria alimentá-lo e cuidar dos seus animais. O visitante era, portanto, considerado como estando sob a proteção do dono da casa durante a sua estada. Naquele período, a hospitalidade estava acima de qualquer lei, incluindo as que regiam as atividades sexuais, questão que é referendada pelo fato de o próprio Ló oferecer suas filhas virgens para a turba. $\mathrm{O}$ castigo da destruição da cidade enfatizava que a violação da hospitalidade era, portanto, a mais grave culpa dos sodomitas.

Com efeito, Sodoma e Gomorra, quando citadas na maioria das fontes bíblicas, não fazem alusão à sexualidade de seus habitantes, o que permitiu a John Boswell analisar o relato com um olhar "não sexualizado", considerando a associação entre os sodomitas e as relações sexuais entre indivíduos do mesmo sexo como uma interpretação distorcida de textos bíblicos. Este pesquisador constatou que essas cidades eram, na verdade, conhecidas ao longo da Bíblia como lugares afeitos a imoralidades de todos os tipos e maus tratos às populações pobres, atributos que lhes fariam objetos de destruição do deus hebraico. ${ }^{9}$

Destarte, o termo sodomia impregnou-se de um forte conteúdo religioso. No século XIII, homens da Igreja procuravam compreender melhor esse relato. Perscrutavam o sentido de cada uma de suas palavras para melhor difundirem a mensagem entre o povo. Os estudos de John Boswell apontam que a construção da imagem erotizada da cidade de Sodoma teria se edificado a partir da teologia de Tomás de Aquino (1225-1274), cuja obra, Suma teológica, foi convertida em norma perante a opinião ortodoxa da Igreja Católica durante quase um milênio. ${ }^{10}$ Foi Aquino quem estabeleceu o termo peccatum contra naturam como pedra de toque da ética sexual católica.

Mas, o que seriam pecados contra naturam? Basicamente, qualquer relacionamento sexual que não visasse à procriação. Medidas contraceptivas, masturbação, bestialidade e a homossexualidade entraram nesse rol de delitos 
sexuais dos quais o cristão deveria abster-se. A percepção da sodomia como algo "antinatural" acentuou-se, portanto, com a elevada importância em definir o comportamento sexual "natural". Por isso, Ronaldo Vainfas afirma que para Tomás de Aquino, "sodomia era o mesmo que relações homossexuais entre homens ou entre mulheres, embora também ele (...) considerasse o coito anal entre machos como a suprema manifestação da "perfeita sodomia". ${ }^{11}$ Aquino se insere, dessa forma, em uma tradição que remonta ao personagem apostólico-cristão Paulo, tido como o primeiro a argumentar que a "lei natural" era apenas a relação entre homem e mulher, em Romanos 1:26-27. A influência de Tomás de Aquino, como se sabe, ultrapassou o século XIII e, no começo do século XVII, "sodomia" já era um conceito intimamente relacionado a atos sexuais "não naturais" e, como bem lembra Phillipe Ariès, graças a essa visão as práticas homossexuais acabaram sendo mergulhadas "no vasto arsenal das perversões" que caracterizariam a sexualidade humana. ${ }^{12}$

Todavia, a palavra sodomia, e esta é a segunda observação, adquiriu um sentido plural. Por suas dimensões, o conceito de sodomia era em tudo momentoso e de uma abrangência que em nada perturbava a força de sua singularidade. Muitos outros termos foram sendo criados ao longo da História da língua portuguesa e assimilados a essa palavra: Amor Sáfico, Amor Socrático, Amor Grego, Vício dos Clérigos, Vício Nefando, Vício dos Nobres, Nefandice, Vício Italiano, Vício Francês, Vício dos Bugres, Velhacaria, Somitigaria e Fanchonice. $^{13}$

Tais sinônimos nada mais fazem senão denunciar o preconceito institucionalizado. ${ }^{14}$ Se o heterossexual é simplesmente o oposto do homossexual, este foi designado ao longo do tempo por uma grande abundância de palavras. Isso já ocorria desde o período colonial, ao menos. Em Portugal, os sodomitas eram, por exemplo, estigmatizados como filhos da dissidência, somítigos, putos, fanchonos. ${ }^{15} \mathrm{Na}$ vizinha Espanha, chamavam-lhes de cabalgados, puñetarios, mariquitas, cotitas, e muitos outros nomes. ${ }^{16}$

$\mathrm{O}$ que interessa reter a partir dessas expressões é o sentido que elas ofereciam entre os séculos XVI ao XVIII: traziam, em seu bojo, além de outras categorizações, a noção de pecado contra a alma, de erro, de vício que causa prejuízo, de algo que atenta contra a procriação. ${ }^{17}$ A palavra sodomia era, portanto, sinônimo de algo ruim, mau, nocivo; ora restringindo-se, ora modificando-se, ela evoluía com uma liberdade invejável. Palavra que se perdia nas explicações, nos incidentes e nas circunstâncias. Seu uso constante manteve sua função cultural: dignificar de modo específico as relações ditas "naturais", atualmente denominadas "heterossexuais".

Isto posto, é possível inferir que o termo sodomia foi sendo ressignificado ao longo das eras, adquirindo um lugar marginal no universo das práticas sexuais. $\mathrm{O}$ sodomita esteve, nesse sentido, confinado ao papel de marginal, excêntrico, criminoso, pecador. $\mathrm{O}$ uso da palavra era uma 
forma de inferiorização do praticante de atos homoeróticos, consequência da hierarquização das sexualidades que conferia um status elevado à heterossexualidade, prática situada no plano do natural. Essas palavras não buscavam outra coisa senão a supressão das diferenças, pela imposição de um único modelo sexual considerado legítimo. O sodomita, portanto, teria em seus atos sexuais a porta de entrada para sua desumanização. Desumanização engendrada pelo critério de um mundo regido pelas oposições, tais como dentrofora, pequeno-grande, masculinidade-feminilidade, úmido-seco, certo-errado, dentre outros sentidos construídos socialmente.

A terceira observação diz respeito à caracterização desse "pecado". Em geral, a sodomia foi assimilada pela Inquisição ao sexo anal com emissão de sêmen dentro do então chamado "vaso traseiro" ou "vas preposterum". ${ }^{18}$ Tratase de uma definição modesta, que não dava conta da pluralidade de práticas eróticas que os homossexuais do passado experimentavam entre quatro paredes. Para Ronaldo Vainfas, a sodomia "passou a significar, enquanto ato, os desvios de genitalidade na cópula entre indivíduos do mesmo sexo ou até de sexo diferente, e com mais frequência o coito anal homossexual ou heterossexual". ${ }^{19}$ Tais indícios levam ao entendimento de que a sodomia estava vinculada ao modelo da cópula heterossexual. $\mathrm{O}$ ato definidor da sodomia era as práticas sexuais anais. Prova-o o desamparo revelado pelos teólogos no entendimento da chamada sodomia foeminarum (lesbianismo):

a maioria dos inquisidores alegou que somente se a mulher introduzisse o sêmen no vaso posterior de outra ficaria caracterizada a perfeita e consumada sodomia, levando-se em conta a impropriedade da vagina para a efetuação do dito crime e a eventual incapacidade do instrumento utilizado para "comunicar sémen agentis no vaso preposterum". A opinião majoritária insistia, pois, na imagem do coito anal como o autêntico ato sodomítico e conjecturava, ainda, sobre o uso de instrumentos, réplicas do falo, para a ocorrência do nefando perfeito. ${ }^{20}$

Os inquisidores, portanto, entendiam o sexo como um ato de penetração. No entendimento do Tribunal do Santo Ofício havia, nessas relações, sempre um "agente" e um "paciente", ou seja, um "dominante" e um "dominado", um que penetrasse e outro que fosse penetrado, um que expelisse o sêmen e outro que o recebesse. O que interessava salientar era "quem fazia o quê a quem". Para os inquisidores, a sodomia poderia comportar dois aspectos: a "sodomia perfeita" referia-se à relação sexual anal com emissão de sêmen entre dois homens. A "sodomia imperfeita" era imputada à relação sexual anal entre homem e mulher, também com emissão de sêmen. Assim sendo: 
As dúvidas e os dilemas inquisitoriais no julgamento do crime de sodomia eram, antes de tudo, de ordem conceitual, questões de princípio que marcavam decisivamente a ação do Tribunal nos processos. Descobrir e interrogar os acusados de sodomia significava, de um lado, proceder contra suspeitos de praticar um ato sexual específico - a penetração anal com ejaculação consumada, fosse entre homens ('sodomia perfeita'), fosse entre homens e mulheres ('sodomia imperfeita) - e, de outro lado, implicava conforme diziam os escolásticos, a descoberta de pecados entre indivíduos do mesmo sexo. ${ }^{21}$

Apesar de a sodomia perfeita não diferir da imperfeita, já que ambas utilizavam o chamado membrum virile (pênis) para obter o gozo sexual por meio do sexo anal, sabe-se que o Tribunal do Santo Ofício possuía "dois pesos e duas medidas" ao julgá-las. Em outras palavras, o coito anal heterossexual não era tão castigado pela Inquisição quanto o era no caso de relações sexuais entre dois homens. Prova disso são os números dos processos inquisitoriais considerados raros por Ronaldo Vainfas quando comparados com os casos de "sodomia perfeita". Segundo esse autor, entre os séculos XVI ao XVIII foram inexpressivas as denúncias e confissões da "sodomia imperfeita". ${ }^{22}$ Os inquisidores, nesses casos, "se limitavam a adverti-los [ao casal heterossexual] do quanto pecavam, instavam-nos a não cometer o nefando e mandavam-nos confessar na sacramental". ${ }^{23}$ Cabe apontar que tais atitudes benevolentes não ocorriam com os casais homossexuais. Ao contrário. "Em matéria de sodomias, os inquisidores só pareciam ter uma única certeza: a de que o abominável nefando (...) só podia ser vasculhado nas relações entre homens". ${ }^{24}$

Por seu turno, para Luiz Mott, a sodomia homossexual foi mais reprimida do que o sexo anal heterossexual por duas razões: pelo fato de os sodomitas desperdiçarem o esperma e por ameaçarem o projeto expansionista português. ${ }^{25}$ Gilberto Freyre também traçou análises interessantes acerca desse projeto expansionista, afirmando que por trás do envio de degredados ao Brasil havia diversos interesses políticos. Nas Colônias, os degredados poderiam exercer uma vida sexual frenética, gerando descendentes que povoassem a terra:

É possível que se degredassem de propósito para o Brasil, visando ao interesse genético ou do povoamento, indivíduos que sabemos terem sido para cá expatriados por irregularidades ou excessos na sua vida sexual: por abraçar e beijar, por usar de feitiçaria para querer bem ou mal, por bestialidade, molície, alcovitice. A ermos tão mal povoados, salpicados, apenas, de gente branca, convinham 
superexcitados sexuais que aqui exercessem uma atividade genésica acima do comum, proveitosa, talvez, nos seus resultados, aos interesses políticos e econômicos de Portugal no Brasil. ${ }^{26}$

A partir dessa definição tão restrita, ou seja, a de que a sodomia era sexo anal com emissão de sêmen, o Tribunal do Santo Ofício acabou "etiquetando" e "identificando" os sodomitas pelo que julgava ser sua preferência sexual: o coito anal. O sêmen adquiria, nesse contexto, o caráter de conteúdo simbólico da procriação. Líquido precioso, ele não deveria ser desperdiçado pelo homem. No que concerne à terminologia anatômica, para a Inquisição havia dois "vasos" no corpo humano:

as mulheres possuem o vaso natural ou dianteiro, onde o membro viril derrama a semente de homem; mulheres e homens possuem o vaso traseiro, também referido nos séculos passados como vaso prepóstero, traseira, via posterior ou via do curso. Em alguns processos inquisitoriais, inclusive no Brasil, percebe-se um temor obsessivo, por parte dos amantes mais descontrolados, de terem inadvertida ou maliciosamente, confundido os vasos, copulando "à moda de Sodoma" em vez de usar o vaso dianteiro. ${ }^{27}$

"Vaso natural" constituía nos séculos XVI ao XVIII um dos muitos termos utilizados para se referir à vagina. ${ }^{28} \mathrm{O}$ vaso natural da mulher era o lugar legítimo para a prática sexual, sendo considerado o espaço apropriado em que o líquido seminal deveria deter-se. O sêmen simbolizava a força da vida e caso esse precioso líquido fosse derramado fora do vaso natural, ele perderia sua função procriativa, constituindo-se em um ato contra naturam. Sexo visava, aos olhos da Igreja, somente à procriação, conforme destacado, devendo os cristãos lutarem contra todo excesso erótico em suas relações sexuais. Dessa forma, segundo William Naphy:

Todos os mandamentos bíblicos referentes ao sexo parecem concentrar-se na necessidade de garantir a procriação a partir de um vasto "fundo genético". Assim, o incesto e a homossexualidade masculina são explicitamente condenados. Convém realçar, porém, que o centro de interesse é a procriação, não a homossexualidade. Se a lei bíblica estivesse realmente preocupada com a homossexualidade então o silêncio total sobre o lesbianismo pareceria inexplicável..$^{29}$ 
Toda a discussão da Igreja em relação ao sêmen, portanto, estabelecia padrões sexuais que impunham restrições a determinados atos. Infundia-se nos homens a ideia de que deveriam sentir prazer apenas por gozos vaginais, depreciando, dentre outras práticas, o sexo anal. Desde os tempos medievais, não era dada aos casais a possibilidade de conhecer seus próprios desejos e sondar suas mais secretas preferências. ${ }^{30}$ Prova disso são os diversos manuais de instrução para confessores disseminados na Europa. Muitos condenavam posições sexuais consideradas heterodoxas: "O único comportamento admissível, dizem eles, é a penetração fecundante, o homem em cima da parceira, sem visar o gozo por si só". ${ }^{31}$ Corroborando tal ideia, Pierre Bourdieu afirma:

Assim como a vagina deve, sem dúvida, seu caráter funesto, maléfico, ao fato de que não só é vista como vazia, mas também como o inverso, o negativo do falo, a posição amorosa na qual a mulher se põe por sobre o homem é também explicitamente condenada em inúmeras civilizações. ${ }^{32}$

O caminho para se entender a origem da perseguição às relações homoeróticas foi discutido no artigo A revolução homossexual: o poder de um mito, de Luiz Mott, em que o autor reconstitui a gênese da homofobia na sociedade portuguesa e brasileira, relendo textos bíblicos à luz de observações históricas, demonstrando que as raízes da intolerância aos chamados sodomitas originaram-se da tradição judaico-cristã. ${ }^{33}$ Para o autor, a sociedade hebraica, da qual a maior parte do Ocidente é religiosamente herdeira, sempre estimulou a procriação, aspirando à longevidade máxima por meio da prole. Os sodomitas eram considerados pecadores, uma vez que suas práticas sexuais não correspondiam a tais objetivos. Análise similar foi realizada pelo pesquisador Francisco Valdes, destacando que as elites judaico-cristãs acreditavam na superioridade do masculino e na ordem patriarcal. ${ }^{34} \mathrm{~A}$ sexualidade não reprodutora - em particular práticas homoeróticas - constituía um grande pecado.

Em meio a essas concepções que permeavam o imaginário social do período, valorizava-se, sobretudo, o sexo vaginal. A interdição religiosa de desperdício do sêmen, herdada da tradição judaica, prescrevia tanto a masturbação quanto o coitus interruptus ${ }^{35}$, não admitindo qualquer ato ejaculatório extravaginal. Entendia-se que homens e mulheres deveriam agir de forma que seus corpos estivessem em harmonia com as funções para as quais a divindade os criara. Práticas que não se enquadrassem na chamada "ordem natural" eram hostilizadas. Tamanha importância era dada à questão do sêmen, elemento sagrado, que a matéria-prima do crime de sodomia era exatamente a "semente do homem" ${ }^{36}$. Isso explica, ao menos em parte, porque o discurso da 
Igreja em relação aos sodomitas voltava-se principalmente aos atos de cópula, penetração e ejaculação intra vas, ou seja, dentro do ânus.

Diante disso, afirma Ronaldo Vainfas:

Fortemente identificada com o coito anal, há muito estigmatizada na tradição ocidental por sua associação com sujeira, excrementos, impureza, demônios, e aproximada ao bestialismo por sugerir a semelhança da cópula com animais, a sem-razão animalesca a que a busca do prazer poderia conduzir, a sodomia não perdeu, no pensamento dos escolásticos, os vínculos que sempre guardara com as condutas homossexuais. ${ }^{37}$

A palavra sodomia é, portanto, uma construção histórica. Simples constatação? Não, se se levar em conta que os arcabouços mentais são prisões de longa duração. Permanências e sobrevivências são vistas no imenso domínio cultural. Isso significa que a sodomia correspondia a uma estrutura de extrema longevidade que teve por função criar subjetividades. Na verdade, o uso dessa palavra durante todo o século XVI e além oculta realidades outras:

A subjetividade é um efeito das linguagens, das práticas linguísticas que determinam suas regras de formação e reconhecimento privado e público. O sujeito, no sentido da experiência subjetiva, nada mais é, na expressão davidsoniana, do que "uma rede de crença e desejos". Seria a versão mais próxima do que em psicanálise postulamos como a correlação necessária entre sujeito e linguagem. As subjetividades então são uma decorrência do uso de nossos vocabulários ou da maneira como ensinamos e aprendemos a ser sujeitos. ${ }^{38}$

Como demonstrado, é fato que esta palavra foi adquirindo novos contornos semânticos. Considerando as análises de Jurandir Freire Costa, o que se denomina "homem homossexual" nada mais seria do que uma realidade linguística. ${ }^{39}$ Algo parecido se aplica à categorização "sodomita", dado que se trata, também, de um sujeito "fabricado" ou "inventado" por um discurso religioso que o dotou de características próprias. ${ }^{40}$ Os termos criam e reproduzem subjetividades diversas. Criando laços discursivos entre os indivíduos e/ou entre eles e as coisas e estados, as palavras estruturam o universo com um sentido compatível com a sobrevida humana.

Trata-se aí de um problema essencial. O homem afirma, consagra, diz. Aqui se depreende a função social da Inquisição: ela separava o sodomita, instituía sua diferença, deslegitimava suas práticas sexuais, consagrava sua diferença. Reconhecendo como legítimas apenas as relações sexuais 
heterossexuais, a Inquisição impunha um limite arbitrário aos indivíduos. Portanto, as palavras e as coisas estão em constante interação como bem o indicou Michel Foucault. É graças as palavras que se pode compreender o que são as coisas. Nesse sentido, o emprego frequente do termo "sodomita" fez com que os homens do passado, tanto na Metrópole quanto na Colônia, acreditassem que existia um tipo humano específico designado por esse adjetivo comum. Isso explica, ao menos em parte, porque para os hábitos linguísticos atuais é quase impossível não associar a sodomia às práticas homoeróticas.

A análise feita até o momento revela que a elaboração de um conceito dificilmente consegue alcançar a transparência de termos exatos. O que importa reter é a maneira como eram caracterizados os sodomitas, uma vez que isso já permite um passo na abordagem do objeto: enquanto inserido dentro de discurso, entendido como um conjunto de enunciados que provêm de um mesmo sistema de formação, a sodomia tomou "forma" a partir desses laços discursivos entre os sujeitos e as práticas. Isso significa reconhecer que a par da noção de "sodomia", o homem ocidental acabou por definir os sujeitos homoeróticos e suas práticas, "etiquetando-os" e "identificando-os" por suas preferências sexuais, as quais passaram a ser reprovadas a partir do momento em que a noção religiosa de pecado passou a integrar-se no imaginário social, estigmatizando tais sujeitos que se afastavam ou transgrediam os ideais sexuais da maioria.

Como se observa, um termo como sodomia pode estar carregado de uma série de significações e elos. Ele é testemunha de movimentos muito mais profundos. Extensível ao infinito liga-se, livremente ou não, a toda uma cadeia de práticas discursivas e de realidades subjacentes, sendo, ao que tudo indica, impossíveis de se desvincularem umas das outras. Na verdade, o uso da palavra sodomia representava apenas um instrumento de reprodução de uma cultura, ou antes, um reflexo dela - por afirmar e estabelecer relações sociais, por impor formas de autocontrole e encorajar determinados comportamentos, condenando outros.

\section{Os dilemas da escrita histórica: o uso "correto" dos conceitos}

Escapando das categorizações da Igreja, a sodomia acabou caindo sob jugo da clínica médica no século XIX. De pecado passou a ser considerada doença, aberração moral e psíquica, ruindo, a partir desse período, todas aquelas noções de infração religiosa. Desses destroços, porém, surgiram termos novos como perversão, anormalidade, desvio, inversão. Michel Foucault buscou, neste sentido, distinguir a sodomia da homossexualidade. Acreditava que o sodomita não passava de um sujeito jurídico de um tipo de ato interdito. A sodomia era definida na legislação pré-moderna, segundo ele, por um ato proibido não sendo considerada uma qualidade ou um padrão de 
comportamento do indivíduo. Homossexual, por outro lado, seria um "doente", um "anormal" ${ }^{41}$ A homossexualidade seria uma "espécie de androginia interior, um hermafroditismo da alma". ${ }^{42}$ Uma nova vigilância teria sido então instituída sobre a sexualidade do indivíduo, não mais com o intuito de salvar sua alma, como o era até o século XVIII, mas para preservar o corpo da "doença".

Todavia, tanto Luiz Mott quanto Ronaldo Vainfas discordam dessa análise realizada por Foucaul ${ }^{43}$. O primeiro argumenta, com base em vários processos por ele analisados, que houve em Portugal, ao menos desde o século XVI, a existência de uma "subcultura gay" muito anterior do que supunha Foucault, entendendo com isso que muitos sodomitas processados pelo Tribunal do Santo Ofício eram tidos como portadores de uma natureza singular. Para corroborar sua ideia, Mott traz para o centro da discussão exemplos de variados sodomitas que, devido a sua afirmação identitária, eram apelidados pelos inquisidores de "incorrigíveis". O segundo, por sua vez, alega que, embora a sodomia designasse um ato ofensivo ao deus cristão, de modo algum se limitou a esse significado. Seus praticantes não devem ser analisados, segundo ele, apenas sob o prisma de criminosos ou desviantes. Na verdade, a sodomia teria sido uma prática imersa entre dilemas e incertezas.

Diante dessa questão convém questionar se o historiador na atualidade deve utilizar em sua escrita o termo sodomita e não homossexual para falar daqueles que foram processados pelo Tribunal da Inquisição por esse delito. Utilizar o termo homossexual poderá causar estranheza aos historiadores mais especializados, dado o fato de que os homens dos séculos XVI e XVII não tinham qualquer conhecimento dessa noção. O historiador poderá, com isso, ser acusado por seus colegas de anacrônico. Mas, seria isso uma análise correta?

Para responder tal questão deve-se ter em mente o conceito de anacronismo. Atitude anacrônica é aquela que rejeita e não comporta na escrita a historicidade dos conceitos, pois cada época constrói mentalmente suas representações sociais, como bem demonstrou o historiador Lucien Febvre, em seu estudo acerca de François Rabelais. ${ }^{44}$ Todavia, é bom lembrar, o anacronismo em qualquer estudo histórico é inevitável. Vários historiadores escreveram, ao longo do tempo, por exemplo, narrativas históricas acerca de determinadas mulheres. Criaram, conforme a época na qual se inseriam, sua própria ideia de Cleópatra, de Joana D’Arc, de Ana Bolena, de Carlota Joaquina e de Maria Stuart. Assim, não conseguiram libertar-se do quadro histórico que eles mesmos criaram. Escrever história sempre foi e sempre será um exercício de anacronia.

Porém, e isso deve ser enfatizado, é verdade que os conceitos não são inocentes. Cabe ao historiador levar em conta a análise de cada atitude a partir da época histórica que os forja. Definir os significados de um ato com o olhar do momento presente é, sem dúvida, um grande perigo. Em relação aos riscos relativos ao tema homossexualidade na história, Philippe Ariès destaca: 
Nem sempre é fácil diagnosticar a homossexualidade [na história]. Não se sabe exatamente quem era homossexual ou quem não era, de tão anacrônicos (os de nossa época) ou tão polêmicos (as acusações de Agripa d'Aubigné contra Henrique III e seus amantes) ou simplesmente tão indecisos que são os critérios. A atitude de nossas antigas sociedades para com a homossexualidade - que conhecemos mal e que seria necessário estudar com um enfoque ao mesmo tempo novo e sem anacronismo psicanalítico - parece mais complexa do que nos levariam a crer os códigos muitos rígidos e muito preciosos da moral religiosa da época. ${ }^{45}$

Lígia Bellini também alertou os historiadores acerca do perigo de aplicar conceitos atuais a um passado que entendia de modo diferente o "desvio sexual". Segundo ela, os termos "sodomia" e "sodomita" possuíam duplo sentido. Muitas vezes, foram utilizados para se referirem à masturbação individual, ao sexo oral, ao bestialismo, à cópula anal heterossexual. ${ }^{46}$

Mas, se o perigo existe, por que o historiador deve utilizar o termo homossexual para falar dos indivíduos do passado acusados de práticas sexuais com outros do mesmo sexo?

Primeiro, porque não há dúvidas de que existiam homossexuais, ou antes, existia uma pluralidade de grupos homossexuais tanto em Portugal como na Colônia entre os séculos XVI ao XVIII, definidos pelo estatuto objetivo de pajens, clérigos, comerciantes, soldados, etc., constantes nos processos inquisitoriais. Todavia, não são os indivíduos e suas respectivas categorias profissionais em si que interessa observar, mas o grupo social a que pertenciam e com o qual partilhavam interesses. Esse grupo possuía realidades e uma subcultura própria, que se pode caracterizar como sendo homossexual.

Luiz Mott talvez tenha sido o primeiro pesquisador a alertar os historiadores brasileiros para a importância da "subcultura gay" em Portugal, mostrando que ela possuía lógicas próprias, que importa decifrar e compreender. Para melhor entender o sodomita do período, convém que se estudem os comportamentos coletivos, sensibilidades, imaginações e gestos a partir de objetos precisos, tais como roupas, linguagens, trejeitos. ${ }^{47}$ A maneira de vestir, por exemplo, traduzia outrora a influência de códigos sociais únicos, realçando aparências: cada um devia parecer o que era. ${ }^{48}$ Não se trata apenas de alargar a narrativa histórica, mas de elaborar uma história que leve em conta os elementos característicos dos homossexuais do passado. Conserva-se, dessa forma, a vontade de compreender as maneiras gerais de sentir, conhecer e pensar, ligando as representações coletivas do grupo às condutas individuais dos sodomitas. Encontra-se aí todo um universo social que propiciou o desenvolvimento de 
estilos de vida. Trata-se de algo que cada homossexual "tinha" e que cultivava dentro de si. Tal subcultura funcionava como um aspecto do eu, de uma identidade e de uma condição.

Deve-se, portanto, observar com atenção a subcultura desses indivíduos. Subcultura que se conecta com o tema da identidade a qual Michel Foucault preferiu silenciar-se. Muitos sodomitas foram capazes de conservar a identidade do grupo, apesar das perseguições religiosas e sociais da época. Essa identidade deve ser levada em consideração para se compreender que, embora mudando continuamente, a homossexualidade sempre manteve características próprias que a acompanharam no decorrer dos tempos. E aqui, convém asseverar, não se está falando aqui de determinada prática sexual localizada em determinado orifício do corpo. Quando a análise histórica passou a se interessar por grupos sociais menos estreitamente definidos, como os homossexuais, muitas de suas características passaram a ganhar consistência. Ora, um grupo só existe na medida em que existe voz e representação. Se os sodomitas foram perseguidos pelo Tribunal Inquisitorial nos séculos passados, só o foram devido a sua representabilidade.

Assim sendo, quando deliberadamente o historiador emprega o vocábulo homossexual para se referir aos sodomitas do Brasil Colonial, pretende ir além da mera definição clássica de "indivíduo que sente atração erótica e sexual por outros do mesmo sexo". Refere-se, também aos sinais distintos, às marcas simbólicas, aos sistemas criados, às táticas utilizadas, às práticas difundidas entre o grupo e que animaram muitos desses indivíduos ao longo do tempo. É o conjunto de representações, a visão de mundo partilhada, a leitura comum do passado e a projeção no futuro vivida em conjunto por esses sujeitos que importa estudar. Muito dessa "subcultura", é claro, ainda está para ser descoberta pelos historiadores. Isso significa conceder na análise histórica uma atenção maior às estruturas, ou seja, aquilo que "se esquiva à mudança", como bem alertou Georges Duby. ${ }^{49}$ Definir os modelos da "subcultura" é dar conta de seu relativo sucesso, percebendo seu movimento, ainda que lento, no decorrer dos tempos, movimento este que também a transforma.

Nesse terreno, ou seja, o do "correto" uso da palavra homossexual e sodomita, os estudos Foucaultianos impuseram seu domínio. Ainda hoje há historiadores que sustentam a tese de Foucault preferindo ocultar a questão da identidade homossexual. Ora, o que este artigo tenta mostrar é exatamente o contrário. A interpretação de Foucault é aqui posta em questão pois, ao invés de simplesmente afirmar que "não havia homossexuais antes do século XIX", reconhece-se que a identidade é, desde sempre, algo valioso, importante e inerente a determinados grupos sociais. Por que seria diferente com os indivíduos que amam o mesmo sexo?

Apreender os sodomitas do passado significa aceitar que compartilhavam de uma subcultura muito similar aos homossexuais da atualidade. Toda vez 
que os historiadores estudam os processos inquisitoriais não é diante de um ato sexual que se detém surpresos. Acima das fronteiras, colocam-se à escuta de fenômenos maiores como gestos, sentimentos, desejos, pois são eles que permitem dar conta não das rupturas, típicas do correr dos anos, mas das singularidades. Todas essas nuances impõem-se do exterior aos indivíduos e elas os guiam, quer eles queiram quer não. Constituem os atributos e nexos que unem os diferentes homossexuais ao longo das eras. São depósitos sedimentados de uma vivência que, sendo excluída a partir da ascensão do cristianismo no Ocidente, nada mais fez senão esconder-se, ocultar-se, dissimular-se. Signos, traços, códigos e linguagens constituem as próprias táticas desses homens perseguidos e muitas vezes marginalizados. O que conta, ao fim e ao cabo, é o caráter representativo dessa subcultura, independente das variações temporais.

Segundo, se o historiador ousa utilizar uma expressão posterior ao século XIX para se referir à sodomia, é embasado em diversos autores que também não hesitam em utilizar expressões como "lésbica", "homossexual", "homossexualidade" e até mesmo "gay" em seus trabalhos. ${ }^{50}$ Os termos criados pelos homens são, portanto, construções históricas. Nesse sentido, tanto sodomia quanto homossexualidade são abstrações utilizadas para um melhor entendimento das experiências sexuais vividas dos homens do passado. Se são utilizadas, é também "por razões práticas de linguagem", para que os leitores menos especializados compreendam, de alguma maneira, o que de fato desejase expressar. ${ }^{51}$

Ao fim e ao cabo, homossexualidade deve ser utilizada exclusivamente como fator de compreensão da realidade ${ }^{52}$. $\mathrm{O}$ historiador não deve aceitar em sua escrita apenas conceitos do passado, excluindo os do presente. Sua obrigação é debruçar-se com desconfiança tanto sobre o que se disse quanto ao que ainda se diz. Entre sodomia e homossexualidade todo o segredo talvez esteja na vírgula. Ainda que signifiquem conceitos separados são, decerto, vizinhos, e invocam uma relação que ainda está por ser mais bem estudada.

\section{Considerações Finais}

Constatação dolorosa: as palavras possuem uma força performativa na construção de subjetividades. A sodomia é exemplo disso, como pretendeu demonstrar este artigo, uma vez que essa palavra, inserida dentro da língua portuguesa passou a ter outros significados, restringindo-se ou modificando-se e, de alguma maneira, evoluindo com uma liberdade invejável. Palavra que se perdeu nas explicações, nos incidentes, nos detalhes e nas circunstâncias.

Por fim, o desuso dos termos "sodomia" ou "sodomita" não é sinal de banimento de suas noções constituintes, mas antes da sua interiorização. Basta notar que, ainda hoje, muitas pessoas associam atos sexuais entre dois homens 
ou entre duas mulheres com "pecado". Esta equivalência, que pode parecer trivial, entre relações homoeróticas e transgressão religiosa não seria antes o efeito da influência que ainda exerce o discurso religioso no uso "correto" do corpo? Essa noção perigosa não constitui uma herança bíblico-linguística que, ao ser inserida no imaginário social, sempre esteve pronta a explodir na brutalidade da homofobia? É ela quem sempre incendiou ao longo da história e, até mesmo hoje, incendeia em tanta autoridade preconceituosa predisposta a torturar, e até mesmo a matar, os que amam o mesmo sexo que lhes caiam às mãos amparada e governada por pretextos religiosos e morais. Ela poderá, contudo, a partir da crescente indignação, tornar-se uma força vital para conter o avanço da intolerância.

\section{NOTAS}

1 Cf. VAINFAS, Ronaldo. Trópico dos Pecados: Moral, Sexualidade e Inquisição no Brasil. Rio de Janeiro: Civilização Brasileira, 2010, p. 194.

2 Cf. BOSWELL, John. Cristianismo, Tolerancia Social y Homosexualidad. Los gays en Europa occidental desde el comienzo de la Era Cristiana hasta el siglo XIV. Traducido del inglés por Marco Aurelio Galmarini. Barcelona: Muchnik Editores SA, 1998. p. 267-286.

3 Palavra de origem hebraica (oтis - Sodom).

4 Segundo John Boswel, o verbo hebraico citado no texto é עדי " עד e significa, basicamente, "conhecer" e não "estuprar". Isso levou alguns exegetas a interpretarem o relato de outra forma: quando os sodomitas se reuniram e pediram que se levassem os anjos a sua presença era porque queriam conhecê-los, saber quem eram, de onde se originavam, demonstrando falta de respeito pela lei da hospitalidade. Na Bíblia usa-se muito poucas vezes este verbo em sentido sexual. Na verdade, consta apenas em 10 das 943 aparições da palavra no Antigo Testamento. Cf. BOSWELL, John. Op. Cit., p. 97. Parece evidente, porém, que o pedido para "conhecer" os visitantes angélicos era um pedido para ter relações sexuais uma vez que Ló ofereceu suas filhas no lugar dos anjos. Todavia, ainda que os homens quisessem ter relações sexuais com os visitantes angélicos, convém questionar se o texto bíblico condenava a "homossexualidade" dos sodomitas ou a violência e o estupro por parte do grupo. Outras interpretações afirmam que o pecado de Sodoma era, na verdade, o sexo entre humanos e anjos e não entre indivíduos do mesmo sexo. Cf. BENETTI, Santos. Sexualidade e erotismo na Bíblia. São Paulo: Paulinas, 1998. p. 46-48. VALLE, E. A Igreja Católica ante a homossexualidade: Ênfases e Deslocamentos de Posições. REVER (Revista de Estudos da Religião), Pós-Graduação em Ciências da Religião, PUC-SP, n1, ano 6, p. 153-185, 2006; LIMA, L. C. Homossexualidade, lei natural e cidadania. Em Debate, n. 6, revista do Depto. de Serviço Social, PUC-Rio, 2007.

\section{Cf. Gênesis 19: 1-11.}

6 O que é surpreendente não é tanto a hostilidade anti-homossexual do passado, mas o uso constante e repetitivo desse relato na atualidade. O cônego José Luiz Villac de São Paulo afirmou certa vez: "Os homossexuais cínicos e agressivos devem merecer dos católicos o repúdio votado a todos os pecadores públicos e insolentes, que se declaram ou se comportam como inimigos de Deus e de Sua Santa Lei. Homossexuais assim são como células cancerosas e pútridas no corpo social. Devem ser repudiados, com nota de execração. Que Nossa Senhora livre o Brasil dessa infâmia. E não permita seja aprovado no Congresso Nacional o torpe projeto de lei que institui o "casamento" entre homossexuais. Isto constituirá uma insolente ofensa feita a Deus 
e a Nossa Senhora pelos legisladores do País, e que atrairá sobre o Brasil grandes castigos, pois será a legalização e a legitimação oficial de um pecado infame que clama a Deus por vingança, alinhando-nos a Sodoma e Gomorra (...)" Cf. MOTT, Luiz; CERQUEIRA, Marcelo. Matei porque odeio gay. Salvador: Editora Grupo Gay da Bahia, 2003. p. 11, grifos nossos.

7 Seletiva porque a Igreja sempre se silenciou acercas de relações homoeróticas entre personagens bíblicos tais como Davi e Jônatas (1 Samuel 18: 20,41. 2 Samuel 1: 23 e 26) e Rute e Noemi (Livro de Rute 1:16-17), relações essas que durante toda a Idade Média foram celebradas na Literatura Eclesiástica. Cf. BOSWELL, John. Op. Cit., p. 104.

8 Cf. JORDAN, Mark D. La Invención de la Sodomia en la Teología Cristiana. Barcelona: Laertes, 2002. p. 19.

9 Em Gênesis 13.13, seis capitulos antes do relato de Ló, o texto bíblico registra pela primeira vez o caráter das pessoas da cidade de Sodoma: "E os homens de Sodoma eram maus e grandes pecadores (...)". É curioso notar que a passagem não faz menção a que tipos de pecados eram praticados pelos sodomitas. Portanto, ao que parece, a sentença da destruição de Sodoma já havia sido dada antes do episódio supostamente "homossexual" de Gênesis 19. Nesse sentido, é interessante notar que quando citadas ao longo da Bíblia, Sodoma e Gomorra não são caracterizadas como "cidades de homossexuais". Isaías 1:9; 13:19 qualifica a injustiça social como o pecado de Sodoma; Ezequiel 16:46-51 destaca os maus-tratos aos pobres como a causadora da ruína da cidade; Jeremias 23: 14 frisa a "imoralidade geral" de seus habitantes; Cf. também, Lamentações 4:6; Amós 4:11; Sofonias 2:9; Mateus, 11:23; Romanos 9:29;. O próprio Jesus, em Lucas 17:28,29, destacou outros motivos para a ruína de Sodoma que não estão ligadas aos relacionamentos sexuais praticados por seus habitantes.

10 Cf. BOSWELL, John. Op. Cit., p. 307.

11 Cf. VAINFAS, Ronaldo. Op. Cit., p. 197, grifos nossos.

12 Cf. ARIÈS, Philippe. Reflexões sobre a história da homossexualidade. In:ARIÈS, P.; BÉJIN, André. (orgs.). Sexualidades Ocidentais: contribuições para a história e para a sociologia da sexualidade. 3. ed. São Paulo: Brasiliense, 1987. p. 80.

$13 \mathrm{O}$ termo nefando - do latim nefandum - significava basicamente "o pecado cujo nome não se pode dizer o nome". É definido ainda como "Coisa indigna de se exprimir em palavras; coisa da qual não se pode falar sem vergonha". Cf. BLUTEAU, Raphael. Vocabulario portuguez \& latino. v. 5, p. 698. A sodomia também foi apelidada de "vício grego","costume árabe" ou "colonial", numa clara alusão que pressupunha que o "mal" sempre vem de fora. Cf. BORILLO, Daniel. Homofobia: História e crítica de um preconceito. Tradução Guilherme João de Freitas Teixeira. Belo Horizonte: Autêntica Editora, 2010. p. 14. "Como apenas a cópula anal constituía crime de sodomia, distinguia-se o sodomita do fanchono, reservandose o segundo termo para os praticantes de molices, isto é, todos os demais atos homoeróticos com exclusão de penetratio cum seminis effusionem in vaso prepostero. Fanchonice é usado também, a partir do século XVI, como sinônimo de efeminação, chamando-se de maricas, mulherengo ou mulherigo ao homem pouco viril, suspeito de ser fanchão" (grifos do autor). Cf. MOTT, Luiz. Pagode português: a subcultura gay em Portugal nos tempos da Inquisição. In: Ciência e Cultura (SBPC/SP), v. 40, fevereiro 1988, p. 130. Segundo Antônio de Morais e Silva, fanchono equivalia à palavra efeminado; é aquele "[...] puto agente, dado ao peccado de molície". Cf. SILVA, Antonio de Moraes. Diccionario de Lingua Portugueza - recopilado dos vocabularios impressos ate agora, e nesta segunda edição novamente emendado e muito acrescentado, por Antonio de Moraes Silva. Lisboa: Typografhia Lacerdina, 1813. v. 2, p. 10.

14 Daniel Borillo destaca que enquanto a heterossexualidade é definida simplesmente como aquele que ama o sexo oposto, o homossexual por, por seu turno, é designado por uma grande 
profusão de vocábulos: " $g a y$, homófilo, pederasta, veado, salsinha, michê, boiola, bicha louca, tia, sandalinha, invertido, sodomita, travesti, lésbica, maria-homem, homaça, hermafrodita, baitola, gilete, sapatão, bissexual". Para o autor, esse excesso de termos não possui outra função senão nomear aquilo que é visto como complexo e controverso, deixando implícito o que é, supostamente, "natural”. Cf. BORILLO, Daniel. Op. Cit., p. 15 e 16.

15 A palavra somítigo também fazia alusão à pessoa mesquinha e sovina. Cf. VAINFAS. $O p$. Cit., p. 201. Puto era o "Agente, ou paciente no pecado nefando". Cf. BLUTEAU, Raphael. Op. Cit., v. 6, p. 838.

16 Cf. VAINFAS, Ronaldo. Op. Cit., p. 201.

17 O padre Gregório Martins Ferreira, deão da Sé do Porto, dizia que a sodomia era proibida por Deus em razão do impedimento da multiplicação da espécie: "se não impedisse a geração, a sodomia seria uma fornicação simples”. FERREIRA Apud MOTT, Luiz. Op. Cit., 1988, p. 131.

18 Em diversos processos inquisitoriais analisados tanto por Luiz Mott quanto por Ronaldo Vainfas o ânus é denominado como "vaso traseiro", "vaso desonesto" ou "vas preposterum".

19 Cf. VAINFAS, Ronaldo. Trópico dos pecados. p. 196.

20 Cf. VAINFAS, R. Op. Cit., p. 268.

21 Cf. VAINFAS, R. Homoerotismo Feminino e o Santo Ofício. In: DEL PRIORE, Mary (org.) História das mulheres no Brasil. 9. ed. São Paulo: Contexto, 2010. p. 119-120.

22 Apesar de escassos, a História já demonstra que houve casos de sodomia entre casais heterossexuais, como o caso de Ana Seixas e seu marido, Manoel Franco, moradores da Capitania de Itamaracá nos idos de 1594. Ana dirigiu-se ao inquisidor para denunciar seu marido que, por duas vezes a penetrara em local proibido. Apresentando-se à mesa inquisitorial, Manoel põe a culpa no fato de estar bêbado e "instigado pela carne". Cf. PRIMEIRA VISITAÇÃO DO SANTO OFÍCIO ÀS PARTES DO BRASIL, 1970, p. 99-102. Outros relatos do Brasil Colonial denunciando atos sodomíticos entre casais heterossexuais nas Visitações inclui o caso de "Jácome de Queiróz, cônego que andou sodomizando duas escravinhas de 6 e 8 anos; Joana Nóbrega, prostituta e feiticeira infamada por atender seus clientes pelo 'vaso traseiro';(...). Excessos eróticos entre homens e mulheres não pareciam ser do interesse da Inquisição, haja vista o desprezo de Heitor Furtado [Visitador] em face da denúncia contra um tal João da Lagoa, acusado de no próprio ato sexual retirar seu membro da vagina de Inês Pousadas e pô-lo na boca da amante, 'sujando-a', conforme as palavras da delatora". CF. VAINFAS, R. Trópico dos pecados. p. 340.

23 id. ibid., p. 341.

24 id. ibid., p. 341.

25 Cf. MOTT, Luiz. Os filhos da dissidência: o pecado da sodomia e sua nefanda matéria. In: Tempo, v. 6, núm. 11, julho. Universidade Federal Fluminense, 2001. p. 45.

26 Cf. FREYRE, G. Casa-grande e Senzala: formação da família brasileira sob o regime da economia patriarcal. São Paulo: Global, 2006. p. 82.

27 MOTT, Luiz. Op. Cit., 2001, p. 44.

28 O hábito de colocar nomes no órgão sexual feminino é comum desde que o ser humano adquiriu algum tipo de cultura. Esses nomes, falados no cotidiano, eram muitas vezes considerados de natureza chula e não adequados aos "bons costumes". Em Portugal, vários eram os termos que se referiam ao "vaso natural" ou "vaso feminino": "as freiras de Santa Ana o chamavam de passarinho; as de Santa Marta, carriso; as de Salvador, clitário; as da Rosa, 
covinha, as de Santa Clara, montezinho; as putas, ave de rapina. VAINFAS, R. Op. Cit., p. 347.

29 Cf. NAPHY, William. Born to be gay: História da Homossexualidade. Lisboa: Edições 70, 2004, p. 38.

30 Cf. ROUGEMONT, Denis de. O amor e o Ocidente. Tradução Paulo Brandi e Ethel Brandi Cachapuz. Rio de Janeiro: Guanabara, 1988, p. 48-50.

31 Cf. MUCHEMBLED, Robert. O orgasmo e o Ocidente. p. 33.

32 Cf. BOURDIEU, P. A dominação masculina. Tradução Maria Helena Kühner. 8. ed. Rio de Janeiro: Bertrand Brasil, 2010. p. 27.

33 Cf. MOTT, Luiz. A revolução homossexual: o poder de um mito. In: Revista USP, n. 49, p. 40-59, março/maio, 2001.

34 Cf. VALDES, Francisco. Unpacking Hetero-Patriarchy: Tracing the Conflation of Sex, Gender \& Sexual Orientation to its Origins. Yale Journal of Law \& the Humanities, v. 8: Iss. 1, Article 7, 1996. p. 161-211.

35 Cf. O relato do pecado de Onã em Gênesis 38:6-10. Contraste com Deuteronômio 23:10,11.

$36 \mathrm{O}$ caráter sagrado do sêmen pode ser observado nas magias eróticas muito comuns na América Portuguesa. A bruxa baiana Nóbrega, já no século XVI, afirmava que, se após a relação sexual, a mulher retirasse da própria vagina o sêmen do amado e o colocasse em um copo de vinho para que ele o tomasse, ficaria o amado apaixonado pela mulher. Cf. DEL PRIORE, M. História do amor no Brasil. 2. ed. São Paulo: Contexto, 2006. p. 53. Gilberto Freyre também destacou o sêmen como uma substância constantemente utilizada por "catimbozeiros" na preparação de feitiços amorosos. Diz o autor: "Aliás a fralda suja de camisa de mulher entra na composição de muita mandinga de amor, como entram outras coisas nojentas. Pêlos do sovaco ou partes genitais. Suor. Lágrimas. Saliva. Sangue. Aparas de unhas. Esperma”. Cf. FREYRE, G. Op. Cit., p. 409.

37 Cf. VAINFAS, R. Op.Cit., p. 196.

38 Cf. COSTA, Freire Jurandir. A inocência e o vício: Estudos sobre o homoerotismo. Rio de Janeiro: Relume-Dumará, 1992, p.15-16.

39 Cf. Id. Ibid., p. 23.

40 Cf. JORDAN, Mark D. Op. Cit., p. 11-21.

$41 \mathrm{O}$ conceito de homossexual foi proposto pelo médico húngaro Benkert. Buscava transferir essa condição sexual do domínio jurídico para o médico tendo como consequência primeira a fabricação de um rótulo que colocava os indivíduos na categoria de doentes psíquicos. Cf. CECCARELLI, Paulo Roberto. Homossexualidade: verdades e mitos. In: Bagoas: revista de estudos gays. Universidade Federal do Rio Grande do Norte, Centro de Ciências Humanas, Letras e Artes. v. 1, n.1 (jul/dez). Natal: EDUFRN, 2007. p. 122.

42 Cf. FOUCAULT, Michel. História da Sexualidade 1: a vontade de saber. p. 51.

43 Cf. MOTT, Luiz. Raízes Históricas da Homossexualidade no Atlântico Lusófono Negro. Texto apresentado à Conferência The Lusophone Black Atlantic in a Comparative Perspective. Centre for the Study of Brazilian Culture and Society. King's College. Londres, 2005. p. 7. Cf. também: Cripto-sodomitas em Pernambuco Colonial. In: Revista Anthropológicas, ano 6, v.13 (2), 2002. p. 1, 33 e 36. Cf. VAINFAS, Ronaldo. Op. Cit., p. 194.

44 Cf. FEBVRE, Lucien. O problema da incredulidade no século XVI: a religião de Rabelais. Tradução Maria Lúcia Machado. São Paulo: Companhia das Letras, 2009. 
45 Cf. ARIÈS, Philippe. Reflexões sobre a história da homossexualidade. In:ARIÈS, P; BÉJIN, André. (orgs.). Sexualidades Ocidentais: contribuições para a história e para a sociologia da sexualidade. 3. ed. São Paulo: Brasiliense, 1987. p. 88.

46 Cf. BELLINI, Ligia. A coisa obscura. Mulher, Sodomia e Inquisição no Brasil Colonial. São Paulo: Brasiliense, 1989, p. 32-33. Pedro de Ábano (1250-1316), famoso médico e filósofo italiano medieval, tentando explicar o que entendia por sodomia afirmou: "Alguns praticam o perverso acto de sodomia esfregando o pénis com a mão [masturbação; mútua ou solitária]; outros esfregando-o entre as coxas [sexo intercrural] de jovens [adolescentes], que é o que mais fazem hoje em dia; e friccionando em volta do ânus e introduzindo nele o pénis da mesma maneira que é introduzido nas partes sexuais da mulher. Cf. ÁBANO apud NAPHY, W. Op. Cit., p. 97. grifos meus.

47 João de Freitas Trancoso, afamado sodomita denunciado à Inquisição lisboeta era "muito efeminado e quebradiço (frágil), fala como mulher, mui delicado, faz maneios e requebros como mulher, até no bailar arremenda a figura de mulher". Cf. MOTT, L. Op. Cit., 1988, p. 140 , grifos nossos.

48 Luiz Mott cita o caso de um travesti lisboeta chamado Sebastião, com idade de vinte e três anos. Diz o pesquisador que Sebastião usava 'um pano em redor de si' como uma saia 'parecendo mais mulher do que homem', havendo semelhantes denúncias de casos como esse, sobretudo entre negros da etnia manicongo. Cf. MOTT, L. Op. Cit., 1988, p. 141, grifos nossos.

49 Cf. DUBY, Georges. A História Cultural. In: RIOUX, Jean-Pierre; SIRINELLI, Jean François. Para uma história cultural. Lisboa: Estampa, 1998. p. 403.

50 Cf. BROWN, Judith C. Atos Impuros: A vida de uma freira lésbica na Itália da Renascença. São Paulo: Brasiliense, 1986; BOSWELL, John. Op. Cit., p. 47-58; RICHARDS, Jeffrey. Sexo, Desvio e Danação. p. 136-152; TREVISAN, João Silvério. Devassos no paraíso: a homossexualidade no Brasil, da colônia à atualidade. 4. ed. Rio de Janeiro: Record, 2000; DOVER, Kenneth James. A Homossexualidade na Grécia Antiga. Tradução de Luís Sérgio Krausz. São Paulo: Nova Alexandria, 1994.

51 Cf. BROWN, apud BELLINI, L. Op. Cit., p. 33.

52 Convém destacar aqui o exame avaliativo realizado por Jurandir Freire Costa em torno do uso dos termos "homossexualismo" e "homossexualidade". O autor teceu ao longo de sua obra, A inocência e o vício, severas críticas acerca dessas palavras, por acreditar que, quem as utiliza, se remete ao vocabulário do contexto médico-legal, psiquiátrico e higienista do século XIX. Costa defende o uso corrente da palavra "homoerotismo" para designar a maneira como as pessoas do mesmo sexo se sentem atraídas, pois, segundo ele, ela não implica pensar tais relações como doença, anormalidade ou perversão. Cf. COSTA, Freire Jurandir. Op. Cit., 1992.

\section{Artigo recebido em abril de 2016. Aceito em julho de 2016.}

